\title{
Ege Üniversitesi Hastanesi merkezi sinir sistemi tümörlerinin epidemiyolojik ve genel sağ kalım özellikleri
}

\section{Epidemiological and overall survival characteristics of central nervous system tumors in Ege University Hospital}

\author{
Erkin Özgiray' ${ }^{1}$ (D) \\ Yeşim Ertan $^{2}$ \\ K. Emre Çalışkan ${ }^{1}$ (i) \\ Taner Akalın ${ }^{2}$ iD \\ Yavuz Anacak ${ }^{5}$ ii \\ Ayfer Haydaroğlu ${ }^{5}$ (iD \\ M. Sedat Çağlı ${ }^{1}$ iD \\ Ulus Şanlı, \\ Taşkın Yurtseven ${ }^{1}$ (iD \\ Serra Kamer ${ }^{5}$ iD \\ ${ }^{1}$ Ege Üniversitesi Tıp Fakültesi, Beyin ve Sinir Cerrahisi Anabilim Dalı, İzmir, Türkiye \\ ${ }^{2}$ Ege Üniversitesi Tıp Fakültesi, Patoloji Anabilim Dalı, İzmir, Türkiye \\ ${ }^{3}$ Ege Üniversitesi Tıp Fakültesi, Medikal Onkoloji Anabilim Dalı, İzmir, Türkiye \\ ${ }^{4}$ Ege Üniversitesi Tıp Fakültesi, Kanserle Savaş Araştırma ve Uygulama Merkezi, İzmir, Türkiye \\ ${ }^{5}$ Ege Üniversitesi Tıp Fakültesi, Radyasyon Onkolojisi Anabilim Dalı, İzmir, Türkiye
}

Öz

Amaç: Bu çalışmanın amacı, Ege Üniversitesi Tıp Fakültesi Hastanesi veri tabanında bulunan, merkezi sinir sistemi (MSS) tümörü tanısı ile tedavi edilen 5877 adet olgunun epidemiyolojik ve genel sağ kalım özelliklerini istatistiksel açıdan değerlendirmek ve literatür ile karşılaştırmaktır.

Gereç ve Yöntem: 1992 ile 2017 yılları arasında Ege Üniversitesi Tıp Fakültesi Hastanesinde tanı alan 5877 adet MSS kanseri olgusu, Ege Üniversitesi Kanserle Savaş, Uygulama ve Araştırma Merkezi'nin (EÜKAM) özel eğitimli ve sertifikalı kanser kayıt elemanları tarafından kayıt altına alınan veriler, Ki-kare testi ve doğrusal modelleme yöntemi kullanılarak analiz edilmiş, $p<0,05$ değeri anlamlı kabul edilmiştir.

Bulgular: EÜKAM verilerine göre 1992 ile 2017 yılları arasında Ege Üniversitesi Tıp Fakültesi Hastanesinde tanı olan toplam kanser olgu sayısı 117139 olarak bulunmuş olup MSS tümörleri, 5877 adet olgu ile tüm kanser olgularının \%5'ini oluşturmuştur. \%66,7 oranında en sık beyin tümörleri izlenmiştir. MSS tümörleri en sık 50-59 yaş aralığında izlenmiştir. Beyin tümörlerinin en sık frontal lob lokalizasyonunda yerleştiği görülmüştür. Beyin tümörleri arasında diffüz astrositik ve oligodendroglial tümörler (\%63) en sık izlenen grup olmuştur. Beyin tümörlerinin toplam sayısında da tüm MSS tümörleriyle benzer şekilde, 1992-2017 yılları arasında doğrusal bir artış izlenmiştir. Beş yıllık sağ kalım oranı, \%86,3 oranı ile meninks tümörlerinde en fazla olduğu bulunmuştur. Sağ kalım oranlarının, 70 yaş ve üzeri grupta en düşük oranda olduğu, glioblastomların, erkeklerde $(\% 60,4)$ daha sık görüldüğü izlenmiştir. Glioblastomlarda ortalama sağ kalım süresi, erkeklerde 11,6 ay, kadınlarda ise 13,3 ay olduğu bulunmuştur.

Sonuç: Genel olarak EÜKAM verileri ve literatür bilgileri örtüşmektedir ve MSS tümörlerinin insidansında artış olduğu; CBTRUS, GLOBOCAN ve Türkiye Kanser İstatistiği verilerinde de izlenmektedir.

Anahtar Sözcükler: Merkezi sinir sistemi tümörleri, epidemiyoloji, sağ kalım, CBTRUS, GLOBOCAN.

\section{Abstract}

Aim: The aim of this study was to evaluate the epidemiological and overall survival characteristics of 5877 patients diagnosed with Central Nervous System tumors in the database of Ege University Faculty of Medicine and compare them with the literature.

Materials and Methods: 5877 cases of CNS cancer diagnosed at Ege University Hospital between 1992 and 2017 were recorded by specially trained and certified cancer registry staff of Ege University Cancer Control, Application and Research Center(EUCRC) analyzed using linear modeling method and Chi-Square test and $p<0.05$ was considered statistically significant.

\footnotetext{
Yazışma Adresi: Erkin Özgiray

Ege Üniversitesi Tıp Fakültesi Beyin ve Sinir Cerrahisi

Anabilim Dalı, İzmir, Türkiye

E-mail: eozgiray@gmail.com
} 
Results: According to EUCRC data, the total number of cancer cases diagnosed at Ege University Hospital between 1992 and 2017 was 117139 and CNS tumors accounted for 5\% of all cancer cases with 5877 cases. $66.7 \%$ of the most common brain tumors were observed. CNS tumors were most frequently observed in the 50-59 age range. Brain tumors were most commonly located in the frontal lobe. Diffuse astrocytic and oligodendroglial tumors (63\%) were the most common group among brain tumors. Similar to all CNS tumors, a linear increase was observed in the total number of brain tumors between 1992 and 2017. The 5-year survival rate was found to be the highest in meningeal tumors with a rate of $86.3 \%$. It was observed that survival rates were the lowest in the 70 -year-old group and Glioblastomas were more common in males (60.4\%). The mean survival time in glioblastomas was 11.6 months for males and 13.3 months for females.

Conclusion: In general, EUCRC data and literature data is overlapping and increase in the incidence of CNS tumors is also seen in the data of CBTRUS, GLOBOCAN and Turkey Cancer Statistics.

Keywords: Central nervous system tumors, epidemiology, survival, CBTRUS, GLOBOCAN.

\section{Giriş}

Merkezi Sinir Sistemi (MSS) tümörleri, anatomik olarak birbirine yakın fakat morfoloji ve klinik davranış olarak birbirinden farklı tümörleri kapsar (1). MSS tümörleri kavramı, genel kullanımda beyin ve omurilik tümörlerini ifade etmek için kullanılsa da 3. Uluslararası Onkolojik Hastalıklar Sınıflamasında (ICD-O-3) meninkslerden, hipofiz bezinden, pineal bezden ve sinirlerden köken alan tümörler, MSS tümörleri olarak; beyin parankiminin tümörleri ise beyin tümörleri olarak değerlendirilmiştir (2). Literatüre bakıldığında ise MSS tümörlerinin beyin, meninks, omurilik, kraniyal sinirler ve diğer MSS lokalizasyonundaki tümörleri kapsadığı görülmektedir (3).

Primer MSS tümörleri, diğer sistem tümörleri ile karşılaştııılıklarında daha az sayıda görülmelerine rağmen, radyolojik inceleme tekniklerinin yaygınlaşması ile bu oran giderek artmaktadır. Histopatolojik inceleme tekniklerinin gelişmesi ile spesifik tümör tiplerinin tanınması kolaylaşmıştır (4).

MSS tümörleri sonucunda gelişen bilinç bozuklukları ve nörolojik kusurlar nedeni ile bu tümörlerin sosyal yükü diğer sistemlerin tümörlerine göre daha belirgindir. Bu nedenle MSS tümörlerinin epidemiyolojisinin anlaşılması, MSS tümörlerinin erken tanı ve tedavisinin sağlanması, yeni tedavi yöntemlerinin geliştirilmesi için önemlidir (5).

$\mathrm{Bu}$ çalışmanın amacı, Ege Üniversitesi Tıp Fakültesi Hastanesi veri tabanında bulunan, MSS tümörleri tanısı ile tedavi edilen 5877 adet olgunun epidemiyolojik ve genel sağ kalım özelliklerini istatistiksel açıdan değerlendirmek ve literatür ile karşılaştırmaktır.

\section{Gereç ve Yöntem}

1992 ile 2017 yılları arasında Ege Üniversitesi Tıp Fakültesi Hastanesinde tanı alan 5877 adet MSS kanseri olgusu, Ege Üniversitesi Kanserle Savaş, Uygulama ve Araştırma Merkezi'nin (EÜKAM) özel eğitimli ve sertifikalı kanser kayıt elemanları tarafından kayıt altına alınmıştır. Kanser kayıtları, nüfus tabanlı kanser kayıt merkezleri için dizayn edilmiş bir bilgisayar programı olan CANREG 4 (IACR-2005) ile kaydedilmiş ve tüm veriler SPSS $₫$ v25'e (IBM-2018) aktarılarak istatistik analizler yapılmıştır. Bu analizler için, MSS tümörleri ICDO-3 kodlarına göre ayrılmıştır: Beyin (C71.0C71.9), meninks (C70.0-C70.9), omurilik, kraniyal sinirler ve MSS diğer bölümleri (C72.0-C72.9), hipofiz bezi, kraniofarengial kanal ve pineal bez (C75.1-C75,3). İstatistik analiz yöntemi olarak, Kikare testi ve doğrusal modelleme yöntemi kullanılmış ve $p<0,05$ değeri anlamlı kabul edilmiştir. Bu çalışmada çocuk yaş grubu, 0-19 yaş aralığı olarak belirlenmiştir.

\section{Bulgular}

\section{Epidemiyoloji}

EÜKAM verilerine göre 1992 ile 2017 yılları arasında Ege Üniversitesi Tıp Fakültesi Hastanesinde tanı olan toplam kanser olgu sayısı 117139 olarak bulunmuş olup MSS tümörleri, 5877 adet olgu ile tüm kanser olgularının \%5'ini oluşturmuştur ve en sık görülen dokuzuncu tümör grubu olmuştur. Tüm sistem kanserlerinin sayı ve oranları Tablo-1'de gösterilmiştir. 
Tablo-1. Tüm sistem kanserlerinin sayı ve oranları.

\begin{tabular}{|l|c|c|}
\hline \multicolumn{1}{|c|}{ Topografik Yerleşim } & Sayı & Yüzde \\
\hline Gastrointestinal Sistem & 19542 & 16,7 \\
\hline Baş ve Boyun & 15401 & 13,1 \\
\hline Solunum Sistemi & 14252 & 12,2 \\
\hline Meme & 13079 & 11,2 \\
\hline Cilt & 9901 & 8,5 \\
\hline Kadın genital Sistemi & 8332 & 7,1 \\
\hline Kan kemik iliği & 6663 & 5,7 \\
\hline Üriner Sistem & 6032 & 5,1 \\
\hline Merkezi Sinir Sistemi & 5877 & 5,0 \\
\hline Erkek genital Sistemi & 5634 & 4,8 \\
\hline Lenf sistemi & 3921 & 3,3 \\
\hline Primeri bilinmeyen & 3450 & 2,9 \\
\hline Yumuşak doku & 1779 & 1,5 \\
\hline Kemik ve Eklem & 1382 & 1,2 \\
\hline Endokrin Sistem & 1200 & 1,0 \\
\hline Nadir tümörler & 331 & 0,3 \\
\hline Göz ve ekleri & 298 & 0,3 \\
\hline $\begin{array}{c}\text { Diğer iyi tanımlanmayan } \\
\text { tümörler }\end{array}$ & 65 & 0,1 \\
\hline TOPLAM & 117139 & 100,0 \\
\hline
\end{tabular}

MSS tümörlerinin görülme oranının, tüm sistemlerin tümörleri ile birlikte değerlendirildiğinde erkeklerde biraz daha fazla olmak ile birlikte her iki cinsiyette, hemen hemen aynı oranda olduğu izlenmiştir. Erkeklerde bu oran \%2,24 (n:2625) iken kadınlarda; \%2,22'dir (n:2611). MSS tümörü tanısı almış olgular incelendiğinde erkek olguların oranı \%50,1 (n:2625), kadın olguların oranı ise \%49,9'dur (n:2611).

MSS tümörleri kendi aralarında lokalizasyonlarına göre değerlendirildiğinde; beyin tümörleri, \%66,7 (n:3490) oranı ile en sık lokalizasyon olarak bulunmuştur. Meninksler; \%23,7 (n:1239), omurilik ve diğer MSS tümörleri ise \%9,7 (n:507) oranında bulunmuştur. MSS tümörlerinin ICD-O-3'e göre yerleşim yerlerinin dağılımı Şekil-1'de gösterilmiştir. MSS tümörlerinin lokalizasyonu ile cinsiyetlerin karşılaştırıması sonucunda ise her iki cinsiyette en sik beyin tümörleri izlenmekle (erkek: \%76 n:1994; kadın: \%73 n:1496) birlikte kadınlarda meninks tümörlerinin erkeklere oranla daha sık izlendiği görülmüştür (\%33 n:861). Omurilik ve diğer MSS tümörleri ise en az izlenen tümörler olmuşlardır. MSS tümörlerinin ICD-O-3'e göre yerleşim yerleri ve cinsiyet ilişkisi, Şekil-2'de gösterilmiştir.

MSS tümörlerinin \%18,2'sinin ( $\mathrm{n}: 954)$ çocuk yaş grubunda (0-19 yaş) görüldüğü ve çocuk yaş grubunda erişkin yaş grubuna benzer şekilde $\% 88,8$ (n:847) oranında beyin tümörlerinin görüldüğü izlenmiştir. Çocuk yaş grubunda meningeal tümörlerin çok az izlenmesi (2,4 n:23) ve beyin tümörlerinin erişkin yaş grubuna göre daha fazla oranda (\%88 n:847) bulunması dikkat çekmiştir ve bu fark istatistiksel olarak anlamlı bulunmuştur $(p<0,0001)$. MSS tümörlerinin, çocuk ve erişkin yaş gruplarına göre lokalizasyonları Şekil-3'te gösterilmiştir.

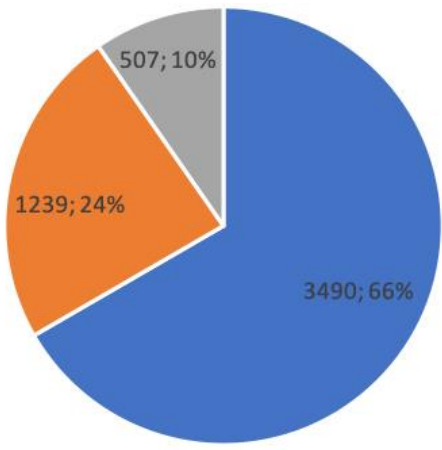

- Beyin $=$ Meninksler $=$ Spinal Kord ve Diğer MSS

Şekil-1. MSS tümörlerinin ICD-O-3'e göre yerleşim yerlerinin dağılımı.

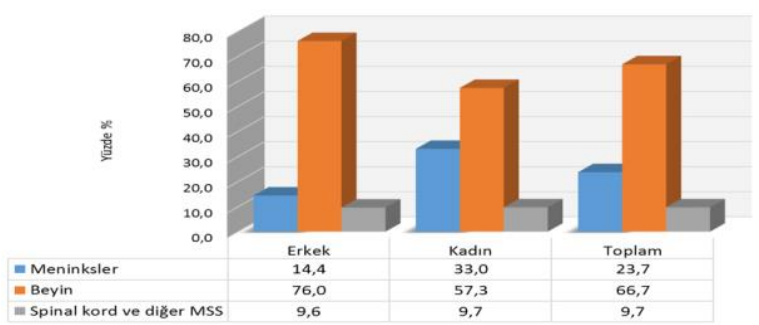

Şekil-2. MSS tümörlerinin ICD-O-3'e göre yerleşim yerleri ve cinsiyet ilişkisi.

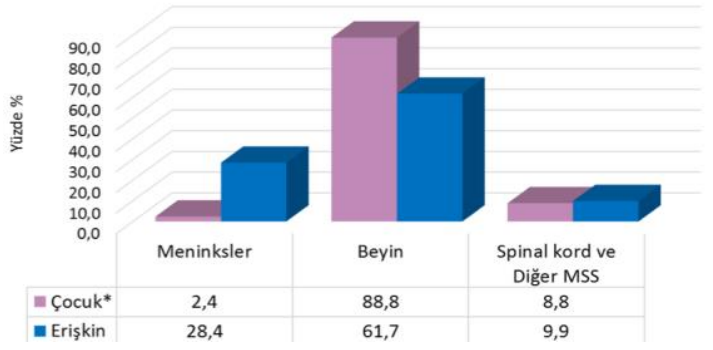

Şekil-3. MSS tümörlerinin çocuk ve erişkin yaş gruplarına göre lokalizasyonları.

Olgular, her dekat için bir grup oluşturulacak şekilde yaş gruplarına ayrılarak değerlendirildiğinde ise MSS tümörlerinin en fazla izlendiği yaş aralığının 50-59 yaş aralığı (\%19,9 n:1042), en az izlendiği yaş aralığının ise 70 yaş üzeri yaş aralığı (\%7,4 n:385) olduğu belirlenmiştir. MSS tümörlerinin yerleşim yerleri ile yaş grupları arasındaki dağılımları incelendiğinde istatistiksel olarak anlamlı bir fark bulunmuştur $(p<0,0001)$. MSS tümörlerinin yerleşim yerlerinin yaş gruplarına göre dağılımı Şekil-4'de gösterilmiştir. 


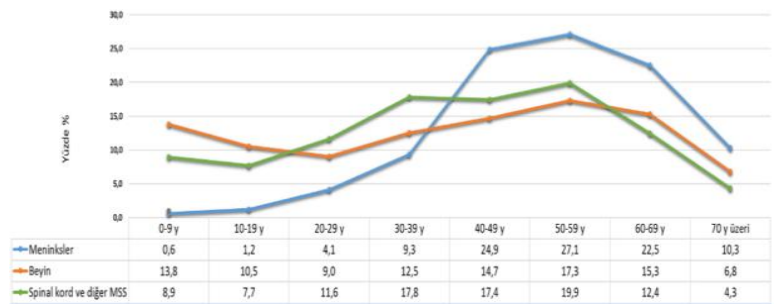

Şekil-4. MSS tümörlerinin yerleşim yerlerinin yaş gruplarına göre dağılımı.
1992 ile 2017 yılları arasında MSS tümörlerinde doğrusal bir artış izlenmiş olup bu doğrusal artış yıllara göre istatistiksel olarak anlamlı bulunmuştur $(p<0,0001)$. MSS tümörlerinin yerleşim yerlerinin yıllara göre dağılımı Şekil-5'te gösterilmiştir.

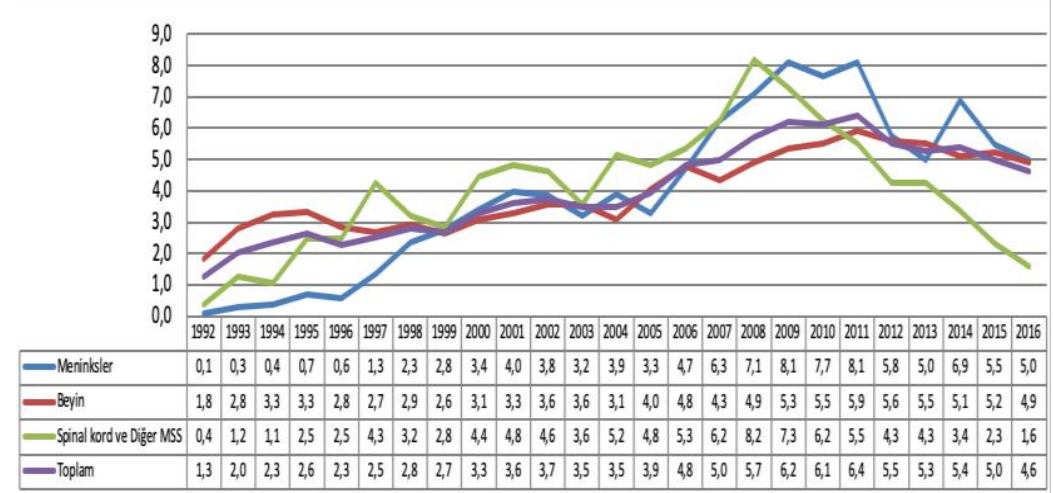

Şekil-5. MSS tümörlerinin yerleşim yerlerinin yıllara göre dağılımı.

Beyin tümörlerinin, lokalizasyonları incelendiğinde en sık frontal lob yerleşiminin (\%15,1 $\mathrm{n}: 527)$ görüldüğü, temporal lobun ise (\%13,9 $\mathrm{n}: 484)$ ikinci en sık yerleşim yeri olduğu izlenmiştir. Oksipital lob $(\% 2,5 \quad \mathrm{n}: 88)$ ve intraventriküler yerleşimin (\%3, n:103) en az yerleşim yerleri olduğu görülmüştür. Erkeklerde temporal lob yerleşiminin (\%15,2 n:304), kadınlarda ise frontal lob yerleşiminin (\%15,9 $\mathrm{n}: 238)$ ilk sırada izlendiği gözlenmiş ve bu fark istatistiksel olarak anlamlı bulunmuştur. $(p<0,0001)$ Beyin tümörü yerleşim yerlerinin, cinsiyetlere göre dağılımı Şekil-6'da gösterilmiştir.

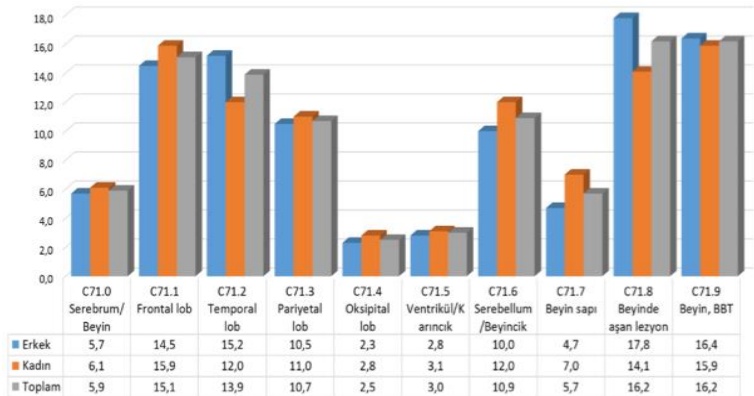

Şekil-6. Beyin tümörü yerleşimlerinin, cinsiyetlere göre dağılımı.

Çocuk yaş grubunda beyin tümörlerinin en sık yerleşim yeri, cerebellum (\%27,2 n:230) ikinci sık yerleşim yeri beyin sapı (\%14 n:119) iken erişkin yaş grubunda en sık yerleşim yerlerinin frontal ve temporal loblar olduğu izlenmiştir. Çocuk yaş grubunda supratentoriyal alanda en sık lokalizasyonun temporal lob (\%7,2 n:61) olduğu bulunmuştur. Beyin tümörlerinin yerleşimlerinin çocuk ve erişki yaş gruplarına göre dağılımı Şekil-7'de gösterilmiştir.

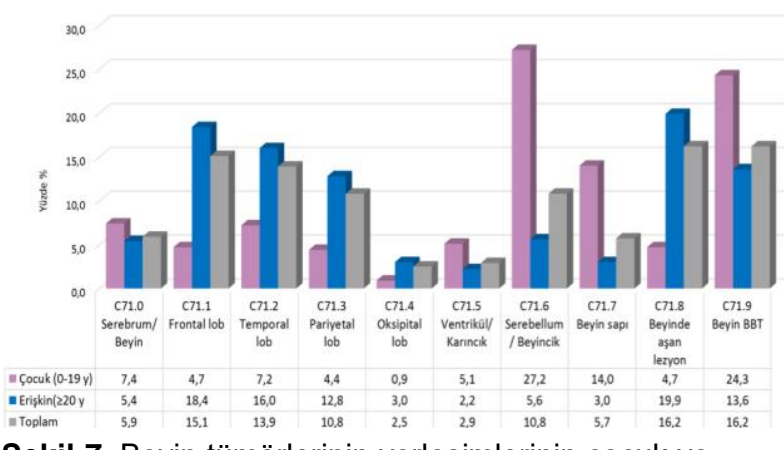

Şekil-7. Beyin tümörlerinin yerleşimlerinin çocuk ve erişki yaş gruplarına göre dağılımı.

Beyin tümörleri, histolojik özelliklerine göre sınıflandırıldığında ise diffüz astrositik ve oligodendroglial tümörlerin $\% 63 \quad$ (n:2423) oranında en fazla izlenen beyin tümörleri olduğu, bunun yanında koroid pleksus tümörleri, sinir tümörleri ve germ hücreli tümörlerin $\% 1$ oranı ile an az görülen tümörler olduğu bulunmuştur. Beyin tümörlerinin histopatolojik olarak sınıflandırılması ve görülme oranları Şekil-8'de gösterilmiştir. 


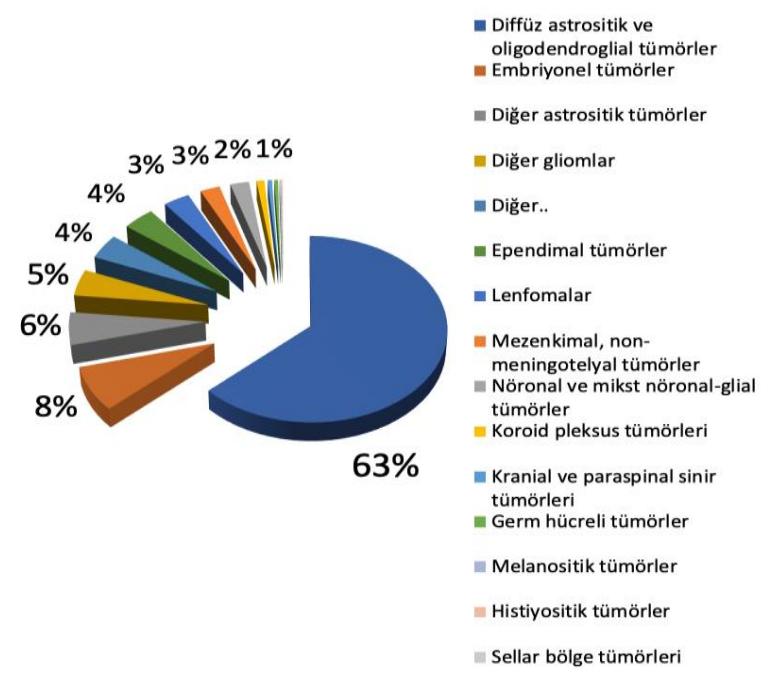

Şekil-8. Beyin tümörlerinin histopatolojik olarak sınıflandırılması ve oranları.
Erkeklerde, $\% 74$ oranında, kadınlarda ise $\% 54,2$ oranında olmak üzere her iki cinsiyette de malign tümörlerin görülme sıklığı daha fazla olsa da erkeklerde malign tümörler, kadınlara göre daha fazla görülürken, kadınlarda benign tümörler erkeklere göre daha fazla görülmüştür ve bu fark istatistiksel olarak anlamlı bulunmuştur. $(p<0,0001)$

Beyin tümörlerinin toplam sayısında da tüm MSS tümörleriyle benzer şekilde, 1992-2017 yılları arasında doğrusal bir artış izlenmiştir. Bu doğrusal artış tüm yerleşim bölgeleri için de izlenmiştir. Genel doğrusal model analizi ile incelendiğinde yıllara göre yerleşim bölgelerindeki artış anlamlı bulunmuştur. (GLM: $F=74,235 ; p<0,0001)$ Beyin tümörlerinin yerleşim yerlerinin yıllara göre dağılımı Şekil-9'da gösterilmiştir.

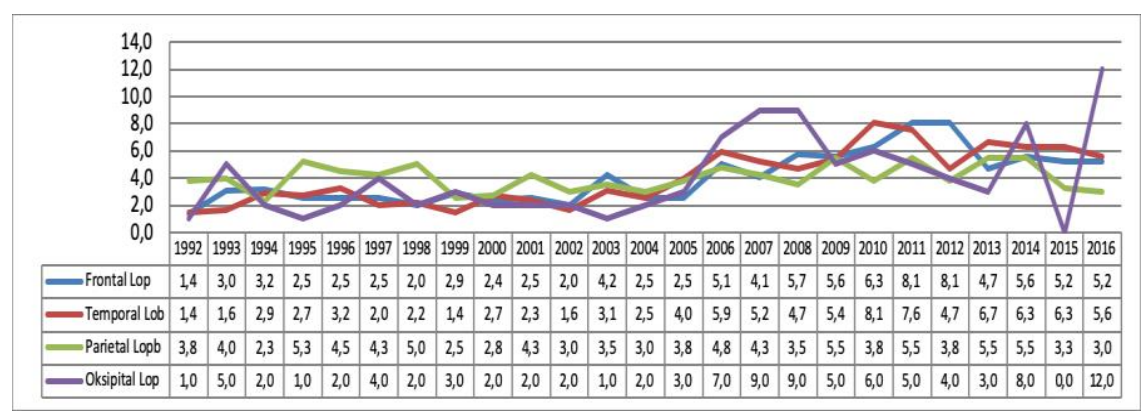

Şekil-9. Beyin tümörlerinin yerleşim yerlerinin yıllara göre dağılımı.

ICD-O-3 sistemi kullanılarak meningeal tümörler yerleşim yerlerine göre sınıflandırılmış ve en sık yerleşim bölgesinin beyin meninksleri (\%81,6 $\mathrm{n}: 1011)$ olduğu bulunmuştur. Spinal meninks yerleşimi ise \%4,1 (n:51) olarak bulunmuştur. Meninks yerleşimli tümörlerin cinsiyet dağılımı incelendiğinde ise her iki cinste beyin meninkslerinde yerleşen tümörlerin birbirine yakın oranlarda olduğu izlenmiştir, bu oran erkeklerde $\% 83$, kadınlarda ise $\% 81,1$ 'dir. Spinal meninks yerleşimli tümörlerin ise kadınlarda $(\% 5)$, erkeklere $(\% 2,8)$ oranla yaklaşık iki kat daha fazla oranda görüldüğü bulunmuştur. Çocuk yaş grubunda meninks yerleşimli tümörler içerisinde beyin meninks yerleşimli tümörler, erişkin yaş grubuna benzer şekilde \%76,2 (n:16) oranında en sık izlenen tümörler iken çocuklarda spinal meninks yerleşimi, \%23,8 oranı ile erişkin yaş grubundan daha fazladır. Bu fark istatistiksel olarak anlamlı bulunmuştur. Çocuk ve erişkin yaş grubunda meninks yerleşimli tümörlerin dağılımı Şekil-10'da gösterilmiştir.

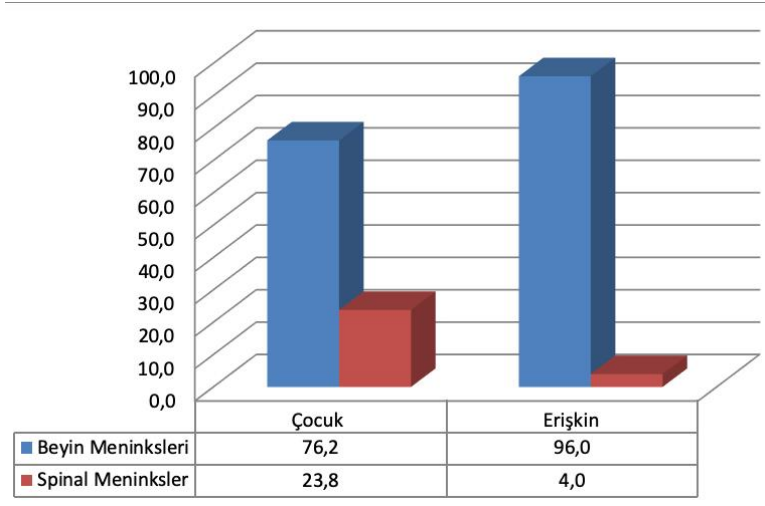

Şekil-10. Çocuk ve erişkin yaş grubunda meniks yerleşimli tümörlerin dağılımı.

\section{Sağ kalım}

Beş yıllık sağ kalım oranı, \%86,3 oranı ile meninks tümörlerinde en fazla olup bunu omurilik ve diğer MSS tümörleri $\% 83$ oranı ile izlemektedir. Beyin tümörlerinde ise beş yıllık sağ kalım oranı, \%46,3 olarak bulunmuştur. 10 yıllık sağ kalım oranları incelendiğinde, omurilik ve diğer MSS tümörlerinin sağ kalım oranı; $\% 79,4$, meninks tümörlerinin, $\% 73$, beyin tümörlerinin 
sağ kalım oranı ise $\% 35,8$ olarak bulunmuştur. MSS tümörlerinin yerleşim yerlerine göre kümülatif sağ kalım oranları Şekil-11'de gösterilmiştir. MSS tümörleri sağ kalım oranlarının cinsiyetlere göre dağılımı incelendiğinde beş yıllık sağ kalım oranı kadınlarda $(\% 66,6)$ erkeklere $(\% 54,5)$ göre daha fazla bulunmuştur. MSS tümörlerinin 10 yıllık sağ kalım oranları ise beş yıllık sağ kalım oranları ile paralel olarak kadınlarda sağ kalım oranı $(\% 57,3)$ erkeklere $(\% 42,8)$ göre daha fazla bulunmuştur. MSS tümörleri ve sağ kalım oranları yaş gruplarına göre incelendiğinde ise 20-29 yaş grubunda beş yıllık sağ kalım oranı, $\% 76,1$ ile en fazla iken 0-9 yaş aralığında ise 10 yıllık sağ kalım oranı, \%62 ile en fazla bulunmuştur. Beş yıllık ve 10 yıllık sağ kalım oranlarının, 70 yaş ve üzeri grupta sırası ile $\% 28,5$ ve $\% 4,1$ ile en düşük oranda olduğu görülmüştür. 70 yaş ve üzeri grupta olguların \%48,3'ü, tanı aldıktan sonraki ilk 12 ayda hayatını kaybetmiştir.

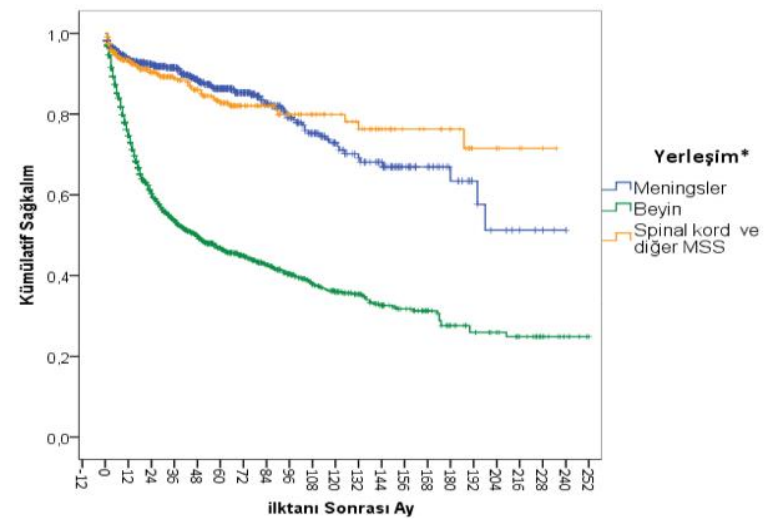

Şekil-11.MSS tümörlerinin yerleşim yerlerine göre kümülatif sağ kalım oranları.

İki yıllık sağ kalım oranları incelendiğinde derece 2 oligodendrogliomların \%87 oranı ile en fazla sağ kalım oranına, glioblastomların ise \%18 oranı ile en düşük sağ kalım oranına sahip olduğu, beş yıllık sağ kalım oranlarının, derece 2 oligidendrogliomlarda (\%58) en yüksek; glioblastomlarda (\%1) ise en düşük olduğu, 10 yıllık sağ kalım oranının ise derece 2 diffüz astrositomlarda (\%23) en yüksek; glioblastomlarda (\%1) ise en düşük olduğu bulunmuştur. Glioblastom tanısı almış olguların $\% 52$ 'si ilk 12 ay içinde hayatını kaybetmiş, ilk 24 aydan sonra ise sağ kalım oranlarında belirgin olarak düşüş kaydedilmiştir. Ortalama sağ kalım süresinin derece 2 oligodendrogliomlarda (112,7 ay) en fazla, glioblastomlarda ise (11,6 ay) en az olduğu izlenmiştir. Gliomların sağ kalım sürelerinin aylara göre dağılımı Şeki-12'de gösterilmiştir.

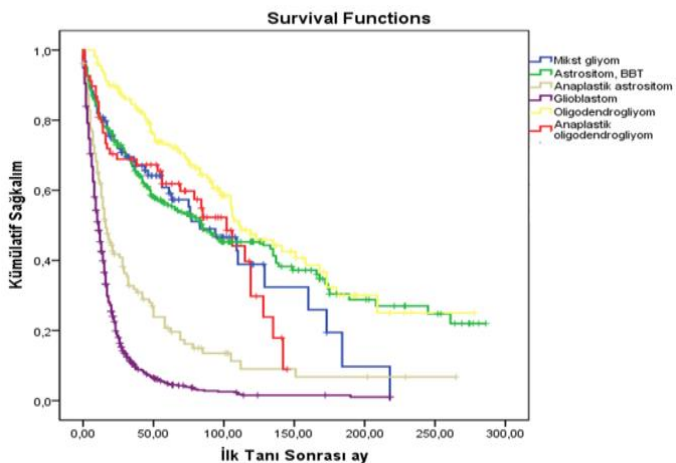

Şekil-12. Gliomların sağ kalım sürelerinin aylara göre dağılımı.

\section{Glioblastom}

Glioblastomların, erkeklerde daha sık görüldüğü izlenmiştir. 1327 adet glioblastom tanısı almış olgunun \%60,4'ünün (n:801) erkek, \%39,6'sının (n: 526) ise kadın olduğu belirlenmiştir. Glioblastomların, ilk üç dekatta daha az görüldükleri ancak dördüncü dekattan sonra görülme sıklığının arttığı ve en sık beş ve altıncı dekatta görüldüğü izlenmiştir. Glioblastomlar, erkeklerde altıncı dekatta $(\% 31,6)$ kadınlarda ise beşinci dekatta $(\% 30,5)$ daha fazla izlenmişlerdir. Glioblastomların, cinsiyet ve yaş gruplarına göre dağılımı Şekil-13'te gösterilmiştir. Glioblastomların en sık temporal lob yerleşimli olduğu, en az ise oksipital loba yerleştiği izlenmiştir. Sırası ile temporal lobda, \%36,3; frontal lobda, \%31,5; pariyetal lobda, \%24,9; oksipital lobda ise $\% 7,3$ oranında yerleştikleri bulunmuştur. Erkekler, $\% 38,5$ oranında temporal lobda en sık, kadınlarda ise $\% 33,9$ oranında frontal lobda yerleştiği izlenmiştir.

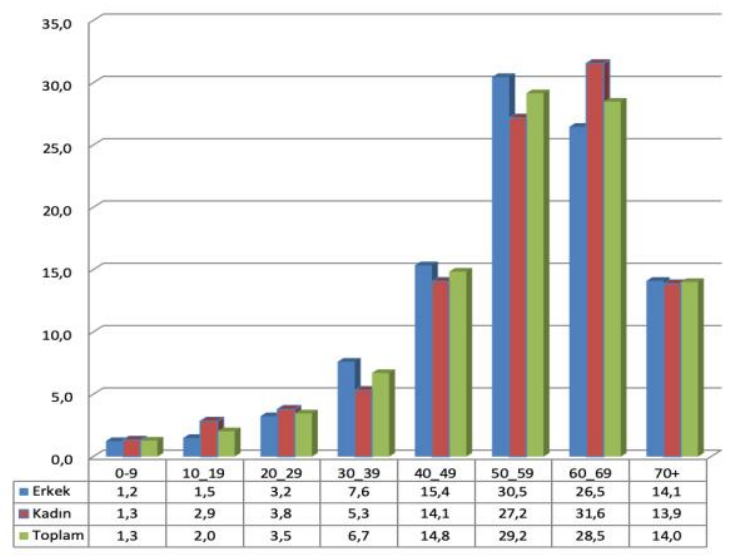

Şekil-13. Glioblastomların cinsiyet ve yaş gruplarına göre dağlımı. 
Glioblastomlarda ortalama sağ kalım süresi, erkeklerde 11,6 ay, kadınlarda ise 13,3 aydır. Erkeklerde sağ kalım oranı ilk 12 ayda \%48,6 iken bu oran ilk 24 ayda \%21,1 olarak bulunmuştur. Kadınlarda ise sağ kalım oranı ilk 12 ayda \%53,2 iken bu oran ilk 24 ayda \%24 olarak bulunmuştur. Sağ kalım oranları her iki cinsiyette de 12. Aydan sonra belirgin olarak düşmüştür ve 60 aylık sağ kalım oranı erkeklerde $\% 4,5$, kadınlarda $\% 5,8 ; 120$ ay sağ kalım oranı ise erkeklerde $\% 0$, kadınlarda $\% 2,6$ oranında bulunmuştur. Glioblastom tanısı almış olguların sağ kalım sürelerinin cinsiyet bağımlı grafiği Şekil-14'de gösterilmiştir.

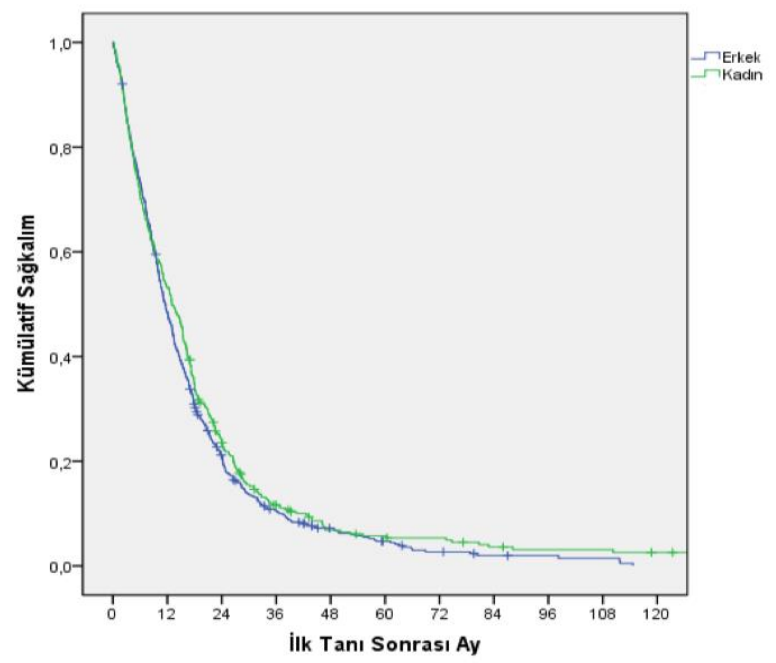

Şekil-14. Glioblastom tanılı olguların cinsiyete bağlı sağ kalım süreleri.

\section{Tartışma}

Bu çalışmada 1992 ile 2017 yılları arasında Ege Üniversitesi Tıp Fakültesi Hastanesinde tanı almış ve EÜKAM'de kayıtlı olan 117139 kanser olgusunun kayıtlı verileri taranmış ve MSS tümörlerinin sayısı 5877 olarak bulunmuştur. Bu veriler ışığında MSS tümörleri en sık dokuzuncu tümör grubu olarak karşımıza çıkarken, CBTRUS verilerine göre sekizinci en sık tümör grubunu oluşturmuştur (6). MSS tümörleri, tüm kanserlerin \%5'ini oluştururken bu değer Uluslararası Kanser Araştırmaları Ajansına (IARC) göre \%1,7'dir (7). CBTRUS verilerine göre MSS tümörlerinin, erkeklerde (\%58) kadınlara (\%42) oranlara daha fazla görüldüğü bildirilmiş ve EÜKAM verileri ile uyumlu olarak bulunmuştur (6). Ayrıca GLOBOCAN verileri ile paralellik göstermektedir (8). Ancak EÜKAM verilerine göre MSS tümörleri erkeklerde $\% 50,1$, kadınlarda ise $\% 49,9$ oranında izlenmiştir. MSS tümörleri içerisinde literatür ile uyumlu olarak, en sık beyin tümörleri görülmüştür (6). MSS tümörlerinin ICD-O-3'e göre yerleşim yerlerinin dağılımı incelendiğinde CBTRUS verilene göre \%36,8 oranında olan meninks yerleşimi, EÜKAM verilerine göre \%23,7 oranında bulunmuştur (6). Ayrıca literatür ile uyumlu olarak meninks yerleşimli tümörlerin, kadınlarda erkeklere oranla daha sık gözlendiği bulunmuştur. Bu durum hormonal faktörler ile açıklanmaktadır (9).

MSS tümörleri, CBTRUS verileri ile paralel olarak çocuk yaş grubunda, erişkinlere göre daha fazla oranda görülmüş ve bu durum EÜKAM verileri ile paralellik göstermektedir (6). Ancak EÜKAM verilerinin değerlendirilmesi sırasında 0-19 yaş aralığı çocuk yaş grubu olarak değerlendirilirken CBTRUS verilerinde çocuk yaş grubu 0-14 yaş aralığı olarak değerlendirilmiştir. EÜKAM verilerinde MSS tümörlerinin en sık görüldüğü yaş aralığı, 50-59 yaş grubu iken CBTRUS verilerinde 85 yaş üstü yaş grubu olarak belirtilmiştir. Ancak medyan yaş, CBTRUS verilerinde 60 yaş olarak bildirilmiş ve bu EÜKAM verileri ile paralellik göstermiştir (6).

MSS tümör olgularının sayısında, literatür ile uyumlu olarak yıllara göre doğrusal ve istatistiksel olarak anlamlı bir artış bulunmuştur $(10,11)$. Literatürde bu durumun nedeni olarak, meningiomların insidansında artış olması gösterilmiştir (12). EÜKAM verilerine göre, 2005 yılından sonra özellikle meninks tümörlerinde artış dikkat çekmektedir. Bunun nedeni olarak radyolojik görüntüleme yöntemlerinin yaygınlaşması, obezitenin artması ve beklenen yaşam süresinin uzaması gösterilebilir (13).

MSS tümörleri, lokalizasyonlarına göre değerlendirildiğinde, EÜKAM verilerine göre frontal lob $(\% 15,1)$ en sık yerleşim yeri olarak bulunmuştur. Frontal lob yerleşiminin oranı, CBTRUS verilerinde \%18,7 olarak bildirilmiştir ve frontal lob, CBTRUS verilerine göre de en sık yerleşim yeridir. Temporal lob yerleşimli tümörlerin oranı, EÜKAM verilerine göre \%13,9 oranında görülürken CBTRUS verilerine göre \%6,0'dır. EÜKAM verilerine göre; frontal lob yerleşimi kadınlarda, temporal lob yerleşimi ise erkeklerde daha fazladır ancak CBTRUS verilerine göre her iki cinsiyette de frontal lob en sık yerleşim yeridir. Erişkinlerde frontal lob ve temporal lob tümörleri ilk iki sırayı alırken literatür ile uyumlu olarak çocuk yaş grubunda cerebellum yerleşimi ön plandadır (6). 
EÜKAM verilerine göre kadınlarda benign tümörlerin, erkeklerde ise malign tümörlerin daha sık görüldüğü saptanmıştır. Bu veriler CBTRUS verileri ile paralellik göstermektedir. EÜKAM verilerine göre benign tümörlerin \%34'ünü kadınların, malign tümörlerin \%74'ünü erkeklerin oluşturduğu; CBTRUS verilerinde ise benign tümörlerin \%60'ını kadınların, malign tümörlerin ise $\% 55,4$ 'ünü erkeklerin oluşturduğu izlenmiştir (6).

EÜKAM verilerine göre meningeal tümörlerin büyük bir çoğunluğunun beyin meninkslerine yerleşim gösterdiği ve kadınlarda daha fazla oranda görüldüğü bulunmuş ve bu veri CBTRUS verileri ile uyumlu bulunmuştur. Çocuk yaş grubunda ise spinal meninks tümörleri, erişkin yaş grubuna göre daha çok olarak bulunmuş ve CBTRUS verileri ile paralellik göstermektedir (6).

EÜKAM verilerine göre astrositik tümörler $\% 63$ oranında, en fazla izlenen beyin tümörleri olmuştur. Astrositik tümörlerin CBTRUS verilerine göre oranı \%75,8'dir. Astrositik tümörlerin büyük bir kısmını oluşturan glioblastomlar ise CBTRUS verilerine paralellik göstererek erkeklerde kadınlardan daha fazla oranda izlenmiştir. CBTRUS verilerinde glioblastomların diğer beyin tümörlerine göre daha geç yaşta, ortalama 65 yaşında daha fazla görüldüğü bildirilmiştir. EÜKAM verileri de bu yönde izlenmiş olup erkeklerde 50-59 yaş grubu, kadınlarda ise 60-69 yaş grubu glioblastomların en fazla oranda izlendiği yaş grupları olarak belirlenmiştir. CBTRUS verilerinde olduğu gibi glioblastomların erkeklerde daha sık görüldüğü EÜKAM verilerinde de izlenmiştir (6).

MSS tümörlerinin erkeklerde genel sağ kalım oranları kadınlara göre daha düşük olmakla birlikte bu farklılık belirgin değildir. Bu durum EÜKAM VE CBTRUS verilerinde paralellik göstermektedir. Literatür ile uyumlu olarak yaş arttıkça sağ kalım oranlarında düşüş izlenmiştir. Beş yıllık sağ kalım oranları, çocuk yaş grubunda $\% 69,8$ iken, 70 yaş üstü grupta literatür verileri ile paralel olarak \%28,5 olarak bulunmuştur. Ancak birçok çalışmada sağ kalım oranlarında farklılıklar izlenmiş olup bu durumun nedeni olarak görüntüleme yöntemlerinin kalitesi ve yaygınlığı, tedavi protokollerindeki farklılıklar, yaşam şekli, genetik farklılıklar öne sürülmüştür. Ancak MSS tümörlerinin CBTRUS ve EÜKAM verilerine göre sağ kalım oranları değerlendirildiğinde birbirine benzer oranlar elde edildiği izlenmiştir. Derece 2 oligodendrogliomların iki yıllık sağ kalım oranları EÜKAM verilerine göre \%87 iken CBTRUS verilerine göre \%89,7'dir (6).

Genel olarak EÜKAM verileri ve literatür bilgileri örtüşse de MSS tümörlerinin insidansı ve sağ kalım oranları; genetik yapı, ülkelerin gelişmişlik seviyeleri, çevresel etkenlerden ve teknolojik gelişmelerden etkilenmektedir. Bu durum MSS tümörlerinin epidemiyolojik özellikleri ve sağ kalım oranlarında, farklı coğrafyalarda farklı sonuçlar alınmasına neden olmaktadır (14). Ancak genel olarak MSS tümörlerinin insidansında artış olduğu, EÜKAM, CBTRUS, GLOBOKAN ve Türkiye Kanser İstatistiği verilerinde izlenmektedir $(6,7,8,15)$.

\section{Teşekkürler}

Olguların operasyonlarında ve izleminde emeği geçen Ege Üniversitesi Tıp Fakültesi Beyin ve Sinir Cerrahisi AD'de görev yapmış Prof. Dr. Nurcan ÖZDAMAR'a, Prof. Dr. Yusuf ERŞAHIN'e, Prof. Dr. İzzet Övül'e, Prof. Dr. Saffet MUTLUER'e, Prof. Dr. Nezih OKTAR'a, Prof. Dr. Kazım ÖNER'e, Prof. Dr. Sertaç IŞLEKEL'e, Prof. Dr. Tayfun DALBASTI'ya, Doç. Dr. Tuncer TURHAN'a teşekkürü bir borç biliriz.

\section{Kaynaklar}

1. Louis D. N., Ohgaki H., Wiestler O. D., et al. "The 2007 WHO classification of tumours of the central nervous system." Acta neuropathologica 2007;114.2.: 97-109.

2. Percy C., Holten V. V., Muir C. S., et al. "International classification of diseases for oncology." 1990.

3. Ostrom Q. T., Gittleman H., Farah P., et al. "CBTRUS statistical report: Primary brain and central nervous system tumors diagnosed in the United States in 2006-2010." Neuro-oncology 15.suppl_2. 2013: ii1-ii56.

4. Lee C. H., Jung K. W., Yoo H., et al. "Epidemiology of primary brain and central nervous system tumors in Korea." Journal of Korean Neurosurgical Society 2010;48. 2: 145.

5. Polednak A P. "Interpretation of secular increases in incidence rates for primary brain cancer in Connecticut adults, 1965-1988." Neuroepidemiology 1996;15.1: 51-6.

6. Ostrom Q. T., Gittleman H., Truitt G., et al. "CBTRUS statistical report: primary brain and other central nervous system tumors diagnosed in the United States in 2011-2015." Neuro-oncology 20.suppl. 2018;4: iv1-iv86. 
7. Ferlay J., Ervik M., Lam F., et al. "Global cancer observatory: Cancer today." Lyon: International Agency for Research on Cancer; 2018.

8. Bray F., Ferlay J, Soerjomataram I, et al. "Global cancer statistics 2018: GLOBOCAN estimates of incidence and mortality worldwide for 36 cancers in 185 countries." CA Cancer J Clin 68: 394-324, 2018

9. Custer B., Longstreth W. T., Phillip, L. E., et al. "Hormonal exposures and the risk of intracranial meningioma in women: a population-based case-control study." BMC cancer 6.1 (2006): 152.

10. Miranda-Filho A., Piñeros M., Soerjomataram I., et al. "Cancers of the brain and CNS: Global patterns and trends in incidence." Neuro-oncology 19(2):270-280, 2016

11. Ilemani C., Matsuda T., Di Carlo V., et al. "CONCORD Working Group: Global surveillance of trends in cancer survival 2000-14 (CONCORD-3): Analysis of individual records for 37513025 patients diagnosed with one of 18 cancers from 322 population-based registries in 71 countries." Lancet 391 (10125): 1023-1075, 2018

12. Lin D. D., Lin J. L., Deng X. Y., et al. "Trends in intracranial meningioma incidence in the United States, 20042015." Cancer medicine 8.14 (2019): 6458-67.

13. Brodbelt A. R., Barclay M. E., Greenberg D., et al. "The outcome of patients with surgically treated meningioma in England: 1999-2013. A cancer registry data analysis." British journal of neurosurgery (2019): 1-7.

14. Wrensch M., Minn Y., Chew T., et al. "Epidemiology of primary brain tumors: Current concepts and review of the literature." Neuro-oncology 4 (4): 278-99.

15. Sencan İ., Keskinkilic B. "Türkiye kanser istatistikleri" Ankara: T.C. Sağılk Bakanlığı Türkiye Halk Sağlığı Kurumu, 2017. 